\title{
30. DIATOM PRODUCTIVITY AND PRESERVATION IN THE WESTERN EQUATORIAL PACIFIC: THE QUATERNARY RECORD ${ }^{1}$
}

\author{
Carina B. Lange ${ }^{2}$ and Wolfgang H. Berger ${ }^{2}$
}

\begin{abstract}
We report on diatom abundance and preservation stratigraphy in the uppermost four cores of Ocean Drilling Program Hole 806B, which span the Quaternary period. Changes in diatom abundance and preservation show a rather complicated pattern, with much noise at high frequencies. However, in the cycles corresponding to eccentricity and obliquity variations, the picture is quite clear. Abundance and preservation follow glacial-interglacial cycles, with lowest abundances and poorest preservation observed in sediments that correspond to glacial stages.

Seventy taxa compose the diatom assemblage of Hole 806B (from Samples 130-806B-1H-1, 8-9 cm, to -4H-7, 73-74 cm) with Azpeitia nodulifera as the dominant member. This species exhibits significant size variations related to glacial and interglacial stages during the Pleistocene.

The distribution of power in the Fourier spectrum of the diatom signal (in the time domain) displays the expected Milankovitch frequencies (at 100,41, and 24-18 k.y.). It also shows concentration at various "odd" frequencies, especially at 62 k.y., suggesting a complicated response of productivity (and silicate chemistry) to climatic forcing.
\end{abstract}

\section{INTRODUCTION}

The patterns of deposition of the remains of diatoms reflect the patterns of upwelling in the ocean margins (Calvert, 1966; DiesterHaass, 1978; Suess and Thiede, 1983; Thiede and Suess, 1983; Lange et al., 1990), as well as in the open ocean (Arrhenius, 1952; Lisitzin, 1972; Berger, 1976; Romine, 1982; Leinen et al., 1986; Pisias and Rea, 1988; Berger and Herguera, 1992). In addition, opal deposition is closely linked to deep circulation in the ocean and internal recycling from dissolution of siliceous tests (Berger, 1970; Johnson, 1974; Pisias, 1976; Barron and Baldauf, 1989) and to geochemical cycles in general, especially with regard to rates of erosion and volcanogenic input (Calvert, 1974, 1983; Heath, 1974; DeMaster, 1981; Milliman and Takahashi, in press). Thus, changes in the rates of accumulation of opal and in the degree of preservation of diatoms, at any one location, may contain information about changes in productivity, deep circulation, and large-scale geochemical processes.

Little is known about silica deposition in the western equatorial Pacific, except for some work on a number of ERDC cores from the Ontong Java Plateau (Mikkelsen, 1978; Boltovskoy, 1989; Herguera, 1992). Much more is known about opal accumulation farther east, where the content of opal in sediments is considerably greater, due to the greater supply of opal from diatom-rich plankton communities (Leinen, 1979; Leinen et al., 1986; Lyle et al., 1988). Measurements of the concentration of biogenic opal in box cores from the eastern equatorial Pacific (PLDS cores) yielded flux values six times higher than in the west (ERDC cores; Herguera, 1992).

Here we document changes in diatom sedimentation for the Quaternary in the western equatorial Pacific to provide clues to the history of ocean productivity and the silica cycle. We present a high-resolution stratigraphic record (10-cm sampling interval) of diatom deposition for the uppermost four cores of Ocean Drilling Program (ODP) Hole $806 \mathrm{~B}$, with emphasis on diatom abundance and state of preservation and with information on species composition and the size distribution of selected species.

\footnotetext{
${ }^{1}$ Berger, W.H., Kroenke, L.W., Mayer, L.A., et al., 1993, Proc. ODP, Sci. Resuits, 130: College Station, TX (Ocean Drilling Program).

${ }^{2}$ Geological Research Division, Scripps Institution of Oceanography, University of California, San Diego, La Jolla, CA 92093, U.S.A.
}

\section{MATERIAL AND METHODS}

Site 806 is located on the northeastern margin of the Ontong Java Plateau, close to the equator $\left(0^{\circ} 19.1^{\prime} \mathrm{N}, 159^{\circ} 21.7^{\prime} \mathrm{E}\right)$ in $2523 \mathrm{~m}$ of water (see Kroenke, Berger, Janecek, et al., 1991, p. 10). The site represents the shallow end-member on a transect that was designed to detect depth-related paleoceanographic signals in Neogene sediments.

Samples were taken at $10-\mathrm{cm}$ intervals. Each sample was first freeze-dried and its dry weight determined. Dry samples were then placed in $400-\mathrm{mL}$ beakers and boiled in hydrogen peroxide (30\%) and sodium pyrophosphate to remove organic matter and to disperse the clay-sized material, followed by treatment with hydrochloric acid to remove calcium carbonate. The samples were then cleansed by washing in distilled water, after which they were allowed to settle for a minimum of $2 \mathrm{hr}$ before the liquid was decanted. The supernatant was checked under the microscope to make sure that the settling time was sufficient and no diatoms were discarded. Generally, five dilution/decanting cycles were necessary to remove the acid. Samples were then diluted to a measured volume, ranging from 20 to $50 \mathrm{~mL}$. Slides of acid-cleaned material were prepared on $22 \times 50 \mathrm{~mm}$ cover glasses and mounted on glass slides using Hyrax mounting medium, following the technique described by Sancetta and Calvert (1988). Generally, two slides were made for each sample. They were examined with a Zeiss photomicroscope under phase contrast illumination. In the case of barren samples, several slides were prepared and examined to assure us that the sample indeed had no diatoms. The identification of species was routinely checked at $500 \times$ and $1250 \times$. The most commonly observed species that compose the typical diatom assemblage for the Pleistocene were photographed with light (LM) and electron microscopy (SEM). They are illustrated in Plates 1 and 2 (LM), and 3 (SEM).

Quick estimates of total diatom abundance were done at 312.5 magnification. About $1025 \times$-microscope fields across each microslide were scanned and the specimens in each field counted; applying the appropriate constants (number of valves counted, area counted, area of microslide covered by the acid-cleaned material, dilution factor, dry weight of sample) permitted calculation of the number of diatom valves per gram of dry sample. The counting convention of Schrader and Gersonde (1978) was adopted. For computing purposes, we have assigned numbers to low-abundance categories such as rare $=0.5$ (if $<1$ specimen per traverse of microslide was observed), barren to rare $=0.25$ (if $<1$ specimen per microslide), 
fragment $=0.1$ (when only a few fragments per microslide were recorded), and barren $=0$ (no diatoms).

We compared our abundance values estimated as described herein ("estimated") with the values calculated ("observed") from counting several traverses across each microslide at 500×; the estimated fall within $20 \%$ of the observed values.

Abundance data are presented as an "abundance index" described by the formula $\log (x / 1000+1)$, where $x$ represents numbers per gram of dry sample.

The preservational state of the diatom assemblage in each sample is described by a "diatom preservation index," which is based upon the species composition of the assemblage, the presence or absence of lightly silicified diatoms (e.g., some Nitzschia), the presence or absence of fine valvar microstructure, and the abundance of fragments. Although this index is mainly qualitative, we have given each state of preservation a number, for computing purposes. The index ranges from 0 (= no diatoms preserved) to 1 (= poor), to 2 (= moderate), to 3 (= good preservation) (cf. Mikkelsen, 1978).

\section{RESULTS}

\section{Time Frame}

High-resolution (at a 10-cm interval) diatom studies were conducted on Cores $130-806 \mathrm{~B}-1 \mathrm{H}$ through $-4 \mathrm{H}$ (Table 1). This interval is represented by $35.25 \mathrm{~m}$ of sediment, a record that spans two diatom zones, the Pseudoeunotia doliolus Zone and the top of the Nitzschia reinholdii Zone (Barron, 1989; see also Kroenke, Berger, Janecek, et al., 1991, p. 28) and which represents the last 1.6 m.y., approximately (see Berger et al., this volume). We have adopted their age model, which is based on the $\delta^{18} \mathrm{O}$ signal of the planktonic foraminifer Globigerinoides sacculifer.

\section{Diatom Abundance and Preservation}

Diatoms were present in most of the downcore samples studied, their abundance varying between 0 and $164 \times 10^{3}$ valves per gram of dry sediment (with the exception of Sample 130-806B-1H, 117-118 $\mathrm{cm}$, with $242 \times 10^{3}$ valves/g), with an overall tendency of sustained lower values between 10.68 and $15.9 \mathrm{~m}$ below seafloor (mbsf). In the abundance index scale, this range is expressed as numbers between 0 and 2.3. Abundance and preservation data are plotted for each core separately and compared with the $\delta^{18} \mathrm{O}$ values (Figs. 1A-1D).

On the whole, abundance and preservation fluctuate together, with high abundance values accompanied by good preservational states and low abundances by poor preservation. The correlation coefficient, $r$, between these two variables is $0.66,0.90,0.88$ and 0.93 , for Cores $130-806 \mathrm{~B}-1 \mathrm{H}$ through $-4 \mathrm{H}$, respectively. Given this high correlation, we present here the results of the analyses based on the diatom abundance data solely, as these data are more nearly quantitative.

There appears to be no obvious correlation of diatom abundance with the $\delta^{18} \mathrm{O}$ record. This impression from an inspection of Figure 1 is confirmed by plotting abundances against the oxygen isotope values for each core, which produces scatter diagrams without much evidence for trends (Figs. 2A-2D). There does seem to be an indication of one kind of pattern, however. Peaks of diatom abundance tend to coincide with negative values of the $\delta^{18} \mathrm{O}$ record (interglacials) and barren samples show a greater probability of association with greater than average $\delta^{18} \mathrm{O}$ values (glacials). These tendencies are counterintuitive, because strong evidence exists that glacial intervals are characterized by increased upwelling activity in the western equatorial Pacific (Herguera and Berger, 1991).

The stratigraphic record of abundance of diatoms allows identification of four major diatom abundance epochs within the Pleistocene, as follows (see Fig. 3): from 0 to $520 \mathrm{ka}(0-10.68 \mathrm{mbsf}$ ), a late Quaternary high-abundance interval (named "Kolbe epoch" for R.W. Kolbe, who first described the distribution of diatoms in deep-sea Quaternary sediments in cores taken by the Swedish Deep-Sea Expe- dition; Kolbe, 1954, 1955, 1957); from 520 to 740 ka (10.68-15.90 mbsf), a mid-Quaternary low-abundance interval (MQL); from 740 $\mathrm{ka}$ to $1.316 \mathrm{Ma}(15.90-26.68 \mathrm{mbsf})$, a mid-Quaternary high-abundance interval (MQH); and from 1.316 to $1.7 \mathrm{Ma} \mathrm{(26.68} \mathrm{mbsf} \mathrm{to} \mathrm{base}$ of record), an early Quaternary cyclic unit (QCU). The mid-Quaternary high-abundance interval can be further subdivided into three subunits, as follows: Subunit a, 740-892 ka, with relatively high abundance values; Subunit b, 892-1025 ka, with reduced abundances, and Subunit c, 1.025-1.316 ka, with sustained high abundance but interrupted by a barren event at about $1.21 \mathrm{Ma}$ ( $25.15 \mathrm{mbsf})$. The boundaries between the units are chosen arbitrarily; they are based on the raw diatom abundance data and the occurrence of barren events.

\section{Fourier Stratigraphy of Diatom Abundance}

Fourier analysis allows the extraction, from the record, of the patterns of fluctuations associated with certain wavelengths of cyclic change, such as astronomical cycles (see Pisias, 1976; Imbrie et al., 1984, for background). The type of analysis here used is the simplest possible expansion into sine and cosine terms (referred to as "harmonics," that is, whole-number fractions of the total length of the record; see Berger et al., this volume). No assumptions are made regarding the influence of "Milankovitch forcing," but such connections to astronomic climate forcing emerge from the analysis.

An extraction of Fourier components (i.e., sums of arbitrarily selected harmonics) with periods greater than 80 ka shows cyclicity in the vicinity of $100 \mathrm{ka}$ (corresponding to the eccentricity of the Earth's orbit), superimposed on a long-term wave with a period near $1 \mathrm{~m} . \mathrm{y}$. (Fig. 4A). The strength of the eccentricity-related component is documented in Figure 4B. The signal is strongest within the Kolbe epoch, but also retains considerable amplitude in the middle and early Pleistocene. The obliquity-related component (Fig. 4C) is important throughout and is especially strong in the early Pleistocene cyclic unit (QCU). There is considerable power within the window of the spectrum that is related to precession (Fig. 4D). However, the signal seems rather irregular, except in the early Pleistocene cyclic unit.

\section{Species Composition}

In all, 70 taxa were observed with Actinocyclus spp., Asteromphalus flabellatus, A. elegans, Azpeitia africana, A. neocrenulata, A. nodulifera, A. sp., H. cuneiformis, Nitzschia marina, Pseudoeunotia doliolus, Roperia tesselata, Rhizosolenia bergonii, Thalassionema nitzschioides, Thalassiosira eccentrica, T. leptopus, T. oestrupii, Thalassiothrix spp., and fragments of Ethmodiscus spp. as common members of the assemblage. The typical diatom flora, as well as some taxa of doubtful taxonomic position, are illustrated in Plates 1,2 and 3.

A. nodulifera (= Coscinodiscus nodulifer $)$ is by far the dominant species throughout, approaching relative abundance values of $>50 \%$ (Fig. 5A). In general, diversity (as estimated by the number of species that make up $80 \%$ of the assemblage) is low, and it does not vary much from sample to sample. However, there is a clear tendency of lowest diversities being recorded in samples from glacial periods, and highest values from interglacials. The same pattern was found by Burckle in Quaternary sediments of the eastern equatorial Pacific from the South American coast to about $140^{\circ} \mathrm{W}$ (L.H. Burckle, pers. comm.)

\section{Size Changes and Quantitative Trends in Azpeitia nodulifera}

Measurements of the diameters of Azpeitia nodulifera (Plate 1, Figs. 1-3; Plate 3, Fig. 1) were made using an eyepiece reticle calibrated with a stage micrometer containing an area of $60 \mu \mathrm{m}$ in diameter to record whether specimens are smaller or greater than 60 $\mu \mathrm{m}$. In general, more than 150-300 specimens of $A$. nodulifera were measured for each sample within the intervals $0-2.5$ and $6.8-8.0$ mbsf. Results are shown (Figs. 5A-5B) as a ratio of small $(<60 \mu \mathrm{m})$ 
Table 1. Diatom data of Cores $130-806 \mathrm{~B}-1 \mathrm{H}$ through $-4 \mathrm{H}$.

\begin{tabular}{|c|c|c|c|c|c|c|c|c|c|}
\hline $\begin{array}{l}\text { Core, section, } \\
\text { interval }(\mathrm{cm})\end{array}$ & $\begin{array}{l}\text { Depth } \\
\text { (mbsf) }\end{array}$ & $\begin{array}{l}\text { Preservation } \\
\text { index }\end{array}$ & $\begin{array}{c}\text { Estimated } \\
\text { diatoms } \\
(* 1000 \text { per } \mathrm{g})\end{array}$ & $\begin{array}{l}\text { Abundance } \\
\text { index }\end{array}$ & $\begin{array}{l}\text { Core, section, } \\
\text { interval }(\mathrm{cm})\end{array}$ & $\begin{array}{l}\text { Depth } \\
\text { (mbsf) }\end{array}$ & $\begin{array}{l}\text { Preservation } \\
\text { index }\end{array}$ & $\begin{array}{c}\text { Estimated } \\
\text { diatoms } \\
(* 1000 \text { per } \mathrm{g})\end{array}$ & $\begin{array}{l}\text { Abundance } \\
\text { index }\end{array}$ \\
\hline $\begin{array}{c}130-806 \mathrm{~B}-1 \mathrm{H}-1, \\
8-9\end{array}$ & & & & & 130-806B-2H-1, & & 0.0 & $0 \Omega 0$ & 000 \\
\hline $\begin{array}{c}8-9 \\
18-19\end{array}$ & $\begin{array}{l}0.08 \\
0.18\end{array}$ & $\begin{array}{l}2.0 \\
2.5\end{array}$ & $\begin{array}{l}151.76 \\
146.31\end{array}$ & $\begin{array}{l}2.18 \\
2.17\end{array}$ & $\begin{array}{l}08-69 \\
78-79\end{array}$ & $\begin{array}{l}7.18 \\
7.28\end{array}$ & $\begin{array}{l}0.0 \\
1.0\end{array}$ & $\begin{array}{l}0.00 \\
9.17\end{array}$ & $\begin{array}{l}0.00 \\
1.01\end{array}$ \\
\hline $38-39$ & 0.38 & 2.5 & 86.62 & 1.94 & 88-89 & 7.38 & 0.0 & 0.00 & 0.00 \\
\hline $48-49$ & 0.48 & 2.5 & 69.84 & 1.85 & $98-99$ & 7.48 & 2.0 & 77.55 & 1.90 \\
\hline $58-59$ & 0.58 & 2.0 & 44.01 & 1.65 & $108-109$ & 7.58 & 3.0 & 56.76 & 1.76 \\
\hline $68-69$ & 0.68 & 2.0 & 50.36 & 1.71 & $118-119$ & 7.68 & 2.5 & 38.29 & 1.59 \\
\hline $78-79$ & 0.78 & 2.0 & 39.24 & 1.60 & $128-129$ & 7.78 & 2.5 & 52.19 & 1.73 \\
\hline $88-89$ & 0.88 & 1.5 & 61.48 & 1.80 & $138-139$ & 7.88 & 2.5 & 50.18 & 1.71 \\
\hline 98-99 & 0.98 & 2.0 & 43.47 & 1.65 & $148-149$ & 7.98 & 2.5 & 50.35 & 1.71 \\
\hline $108-109$ & 1.08 & 1.5 & 40.65 & 1.62 & & & & & \\
\hline $117-118$ & 1.17 & 1.5 & 73.93 & 1.87 & $130-806 \mathrm{~B}-2 \mathrm{H}-2$, & & & & \\
\hline $127-128$ & 1.27 & 0.5 & 5.53 & 0.81 & $8-9$ & 8.08 & 1.5 & 47.37 & 1.68 \\
\hline $138-139$ & 1.38 & 2.0 & 26.82 & 1.44 & $18-19$ & 8.18 & 2.0 & 14.90 & 1.20 \\
\hline \multirow[t]{2}{*}{$146-147$} & 1.46 & 2.0 & 65.26 & 1.82 & $27-28$ & 8.27 & 1.5 & 8.75 & 0.99 \\
\hline & & & & & $38-39$ & 8.38 & 1.5 & 6.61 & 0.88 \\
\hline 130-806B-1H-2, & & & & & $48-49$ & 8.48 & 2.0 & 12.10 & 1.12 \\
\hline $8-9$ & 1.58 & 2.0 & 79.71 & 1.91 & $58-59$ & 8.58 & 2.0 & 50.38 & 1.71 \\
\hline $18-19$ & 1.68 & 0.5 & 4.82 & 0.77 & $68-69$ & 8.68 & 2.0 & 26.49 & 1.44 \\
\hline $28-29$ & 1.78 & 1.0 & 27.35 & 1.45 & $78-79$ & 8.78 & 2.0 & 19.90 & 1.32 \\
\hline $38-39$ & 1.88 & 1.5 & 42.99 & 1.64 & $88-89$ & 8.88 & 2.0 & 26.19 & 1.43 \\
\hline $48-49$ & 1.98 & 2.0 & 47.32 & 1.68 & $98-99$ & 8.98 & 1.5 & 25.91 & 1.43 \\
\hline $58-59$ & 2.08 & 1.5 & 40.60 & 1.62 & $108-109$ & 9.08 & 1.5 & 14.58 & 1.19 \\
\hline $68-69$ & 2.18 & 2.0 & 67.66 & 1.84 & $118-119$ & 9.18 & 0.5 & 3.26 & 0.63 \\
\hline $78-79$ & 2.28 & 2.0 & 57.28 & 1.77 & $128-129$ & 9.28 & 2.0 & 12.85 & 1.14 \\
\hline $88-89$ & 2.38 & 2.5 & 33.35 & 1.54 & $138-139$ & 9.38 & 1.5 & 14.48 & 1.19 \\
\hline $98-99$ & 2.48 & 3.0 & 39.66 & 1.61 & $148-149$ & 9.48 & 2.0 & 15.45 & 1.22 \\
\hline $107-108$ & 2.57 & 2.0 & 105.89 & 2.03 & & & & & \\
\hline $117-118$ & 2.67 & 2.5 & 90.77 & 1.96 & 130-806B-2H-3, & & & & \\
\hline $127-128$ & 2.77 & 2.5 & 116.37 & 2.07 & $8-9$ & 9.58 & 2.0 & 5.30 & 0.80 \\
\hline $138-139$ & 2.88 & 2.5 & 33.88 & 1.54 & $18-19$ & 9.68 & 2.0 & 8.21 & 0.96 \\
\hline \multirow[t]{2}{*}{$146-147$} & 2.96 & 2.0 & 43.65 & 1.65 & $27-28$ & 9.77 & 0.0 & 0.00 & 0.00 \\
\hline & & & & & $38-39$ & 9.88 & 1.5 & 10.67 & 1.07 \\
\hline 130-806B-1H-3, & & & & & $48-49$ & 9.98 & 2.5 & 48.04 & 1.69 \\
\hline $8-9$ & 3.08 & 0.0 & 0.00 & 0.00 & $58-59$ & 10.08 & 3.0 & 44.81 & 1.66 \\
\hline $18-19$ & 3.18 & 2.0 & 11.87 & 1.11 & $68-69$ & 10.18 & 2.5 & 45.10 & 1.66 \\
\hline $28-29$ & 3.28 & 1.5 & 20.07 & 1.32 & $78-79$ & 10.28 & 2.5 & 60.69 & 1.79 \\
\hline $38-39$ & 3.38 & 0.0 & 0.00 & 0.00 & $88-89$ & 10.38 & 2.5 & 72.73 & 1.87 \\
\hline $48-49$ & 3.48 & 1.0 & 3.77 & 0.68 & 98-99 & 10.48 & 2.0 & 36.87 & 1.58 \\
\hline $58-59$ & 3.58 & 2.5 & 41.21 & 1.63 & $108-109$ & 10.58 & 1.5 & 11.11 & 1.08 \\
\hline $68-69$ & 3.68 & 3.0 & 76.15 & 1.89 & $118-119$ & 10.68 & 0.0 & 0.00 & 0.00 \\
\hline $78-79$ & 3.78 & 2.5 & 13.37 & 1.16 & $128-129$ & 10.78 & 0.0 & 0.00 & 0.00 \\
\hline $88-89$ & 3.88 & 2.5 & 38.07 & 1.59 & $138-139$ & 10.88 & 1.5 & 13.66 & 1.17 \\
\hline $98-99$ & 3.98 & 3.0 & 43.05 & 1.64 & $148-149$ & 10.98 & 0.0 & 0.00 & 0.00 \\
\hline $106-107$ & 4.06 & 2.5 & 27.33 & 1.45 & & & & & \\
\hline \multirow[t]{2}{*}{$117-118$} & 4.17 & 2.0 & 242.55 & 2.38 & $130-806 \mathrm{~B}-2 \mathrm{H}-4$ & & & & \\
\hline & & & & & $8-9$ & 11.08 & 0.5 & 1.18 & 0.34 \\
\hline 130-806B-1H-4, & & & & & $17-18$ & 11.17 & 0.0 & 0.00 & 0.00 \\
\hline $8-9$ & 4.58 & 2.0 & 14.49 & 1.19 & $27-28$ & 11.27 & 1.5 & 19.85 & 1.32 \\
\hline $18-19$ & 4.68 & 2.5 & 22.69 & 1.37 & $38-39$ & 11.38 & 0.0 & 0.00 & 0.00 \\
\hline $28-29$ & 4.78 & 3.0 & 39.50 & 1.61 & $48-49$ & 11.48 & 0.0 & 0.00 & 0.00 \\
\hline $38-39$ & 4.88 & 3.0 & 29.81 & 1.49 & $58-59$ & 11.58 & 0.5 & 10.35 & 1.06 \\
\hline $48-49$ & 4.98 & 1.5 & 26.61 & 1.44 & $68-69$ & 11.68 & 1.5 & 51.16 & 1.72 \\
\hline $58-59$ & 5.08 & 2.5 & 26.47 & 1.44 & $78-79$ & 11.78 & 0.0 & 0.00 & 0.00 \\
\hline $68-69$ & 5.18 & 2.0 & 5.05 & 0.78 & $88-89$ & 11.88 & 0.0 & 0.00 & 0.00 \\
\hline $74-75$ & 5.24 & 2.0 & 1.92 & 0.47 & $98-99$ & 11.98 & 2.0 & 20.43 & 1.33 \\
\hline $88-89$ & 5.38 & 2.0 & 24.03 & 1.40 & $108-109$ & 12.08 & 2.0 & 13.62 & 1.16 \\
\hline 98-99 & 5.48 & 1.5 & 22.39 & 1.37 & $118-119$ & 12.18 & 2.0 & 12.59 & 1.13 \\
\hline $106-107$ & 5.56 & 0.5 & 4.30 & 0.72 & $128-129$ & 12.28 & 2.0 & 4.95 & 0.77 \\
\hline $116-117$ & 5.66 & 0.0 & 0.00 & 0.00 & $138-139$ & 12.38 & 2.0 & 20.32 & 1.33 \\
\hline $127-128$ & 5.77 & 2.0 & 2.76 & 0.57 & & & & & \\
\hline $138-139$ & 5.88 & 2.0 & 3.18 & 0.62 & 130-806B-2H-5, & & & & \\
\hline \multirow[t]{2}{*}{$146-147$} & 5.96 & 2.0 & 6.47 & 0.87 & $8-9$ & 12.58 & 0.5 & 1.29 & 0.36 \\
\hline & & & & & $18-19$ & 12.68 & 0.0 & 0.00 & 0.00 \\
\hline 130-806B-1H-5, & & & & & $28-29$ & 12.78 & 0.0 & 0.00 & 0.00 \\
\hline $8-9$ & 6.08 & 1.5 & 2.46 & 0.54 & $34-35$ & 12.84 & 0.0 & 0.00 & 0.00 \\
\hline $18-19$ & 6.18 & 0.0 & 0.00 & 0.00 & $48-49$ & 12.98 & 1.5 & 18.48 & 1.29 \\
\hline \multirow[t]{2}{*}{$28-29$} & 6.28 & 3.0 & 49.02 & 1.70 & $58-59$ & 13.08 & 2.0 & 4.58 & 0.75 \\
\hline & & & & & $67-68$ & 13.17 & 2.5 & 10.44 & 1.06 \\
\hline 130-806B-2H-1, & & & & & $77-78$ & 13.27 & 2.0 & 39.64 & 1.61 \\
\hline $8-9$ & 6.58 & 2.0 & 51.14 & 1.72 & $87-88$ & 13.37 & 2.0 & 15.48 & 1.22 \\
\hline $19-20$ & 6.69 & 2.0 & 8.87 & 0.99 & $97-98$ & 13.47 & 2.0 & 7.68 & 0.94 \\
\hline $29-30$ & 6.79 & 2.0 & 3.03 & 0.61 & $107-108$ & 13.57 & 1.0 & 3.44 & 0.65 \\
\hline $38-39$ & 6.88 & 2.0 & 39.28 & 1.61 & $117-118$ & 13.67 & 2.0 & 13.32 & 1.16 \\
\hline $48-49$ & 6.98 & 1.5 & 31.60 & 1.51 & $127-128$ & 13.77 & 1.0 & 5.37 & 0.80 \\
\hline $58-59$ & 7.08 & 1.0 & 11.80 & 1.11 & $137-138$ & 13.87 & 0.0 & 0.00 & 0.00 \\
\hline
\end{tabular}


Table 1 (continued).

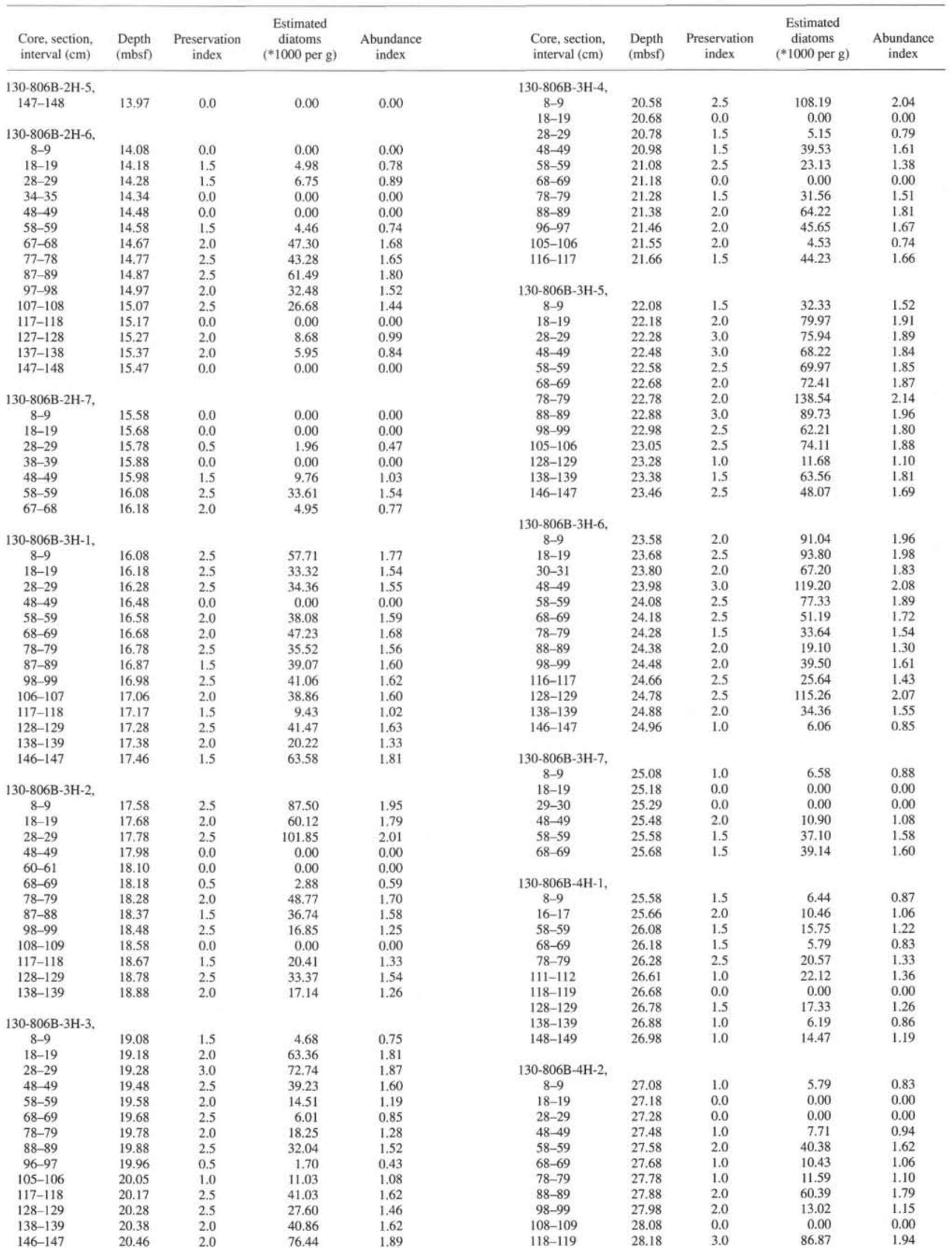


Table 1 (continued).

\begin{tabular}{|c|c|c|c|c|}
\hline $\begin{array}{l}\text { Core, section, } \\
\text { interval }(\mathrm{cm})\end{array}$ & $\begin{array}{l}\text { Depth } \\
\text { (mbsf) }\end{array}$ & $\begin{array}{l}\text { Preservation } \\
\text { index }\end{array}$ & $\begin{array}{c}\text { Estimated } \\
\text { diatoms } \\
(* 1000 \text { per } g)\end{array}$ & $\begin{array}{l}\text { Abundance } \\
\text { index }\end{array}$ \\
\hline \multicolumn{5}{|l|}{$130-806 \mathrm{~B}-4 \mathrm{H}-2$, } \\
\hline $128-129$ & 28.28 & 2.0 & 81.45 & 1.92 \\
\hline $138-139$ & 28.38 & 2.0 & 89.71 & 1.96 \\
\hline $148-149$ & 28.48 & 2.0 & 45.08 & 1.66 \\
\hline \multicolumn{5}{|l|}{ 130-806B-4H-3, } \\
\hline $8-9$ & 28.58 & 1.5 & 19.65 & 1.31 \\
\hline $18-19$ & 28.68 & 1.5 & 6.79 & 0.89 \\
\hline $48-49$ & 28.98 & 0.0 & 0.00 & 0.00 \\
\hline $58-59$ & 29.08 & 0.0 & 0.00 & 0.00 \\
\hline $68-69$ & 29.18 & 1.0 & 29.81 & 1.49 \\
\hline $78-79$ & 29.28 & 1.0 & 41.60 & 1.63 \\
\hline $88-89$ & 29.38 & 2.0 & 32.89 & 1.53 \\
\hline $98-99$ & 29.48 & 2.0 & 40.39 & 1.62 \\
\hline $108-109$ & 29.58 & 2.0 & 18.99 & 1.30 \\
\hline $118-119$ & 29.68 & 2.0 & 20.18 & 1.33 \\
\hline $128-129$ & 29.78 & 2.0 & 39.44 & 1.61 \\
\hline $138-139$ & 29.88 & 0.0 & 0.00 & 0.00 \\
\hline $148-149$ & 29.98 & 0.0 & 0.00 & 0.00 \\
\hline \multicolumn{5}{|l|}{$130-806 \mathrm{~B}-4 \mathrm{H}-4$, } \\
\hline $8-9$ & 30.08 & 1.0 & 15.38 & 1.21 \\
\hline $18-19$ & 30.18 & 2.0 & 40.40 & 1.62 \\
\hline $28-29$ & 30.28 & 2.0 & 36.61 & 1.58 \\
\hline $48-49$ & 30.48 & 2.0 & 45.53 & 1.67 \\
\hline $58-59$ & 30.58 & 2.0 & 52.25 & 1.73 \\
\hline 68-69 & 30.68 & 2.0 & 41.21 & 1.63 \\
\hline $78-79$ & 30.78 & 1.0 & 33.63 & 1.54 \\
\hline $88-89$ & 30.88 & 0.5 & 7.74 & 0.94 \\
\hline $98-99$ & 30.98 & 3.0 & 164.85 & 2.22 \\
\hline $118-119$ & 31.18 & 0.0 & 0.00 & 0.00 \\
\hline $128-129$ & 31.28 & 2.0 & 32.62 & 1.53 \\
\hline $138-139$ & 31.38 & 1.5 & 24.04 & 1.40 \\
\hline \multicolumn{5}{|l|}{ 130-806B-4H-5, } \\
\hline $8-9$ & 31.58 & 1.5 & 31.54 & 1.51 \\
\hline $18-19$ & 31.68 & 1.5 & 17.81 & 1.27 \\
\hline $28-29$ & 31.78 & 2.0 & 81.94 & 1.92 \\
\hline $48-49$ & 31.98 & 0.0 & 0.00 & 0.00 \\
\hline $58-59$ & 32.08 & 1.5 & 24.39 & 1.40 \\
\hline $68-69$ & 32.18 & 1.0 & 17.81 & 1.27 \\
\hline $78-79$ & 32.28 & 1.0 & 11.35 & 1.09 \\
\hline $88-89$ & 32.38 & 2.0 & 41.47 & 1.63 \\
\hline 98-99 & 32.48 & 2.5 & 96.00 & 1.99 \\
\hline $108-109$ & 32.58 & 2.5 & 74.59 & 1.88 \\
\hline $118-119$ & 32.68 & 0.0 & 0.00 & 0.00 \\
\hline $128-129$ & 32.78 & 1.0 & 8.07 & 0.96 \\
\hline $138-139$ & 32.88 & 1.5 & 26.70 & 1.44 \\
\hline $148-149$ & 32.98 & 2.5 & 64.41 & 1.82 \\
\hline \multicolumn{5}{|l|}{ 130-806B-4H-6, } \\
\hline $8-9$ & 33.08 & 2.0 & 47.43 & 1.69 \\
\hline $18-19$ & 33.18 & 2.5 & 46.06 & 1.67 \\
\hline $28-29$ & 33.28 & 2.0 & 40.89 & 1.62 \\
\hline $48-49$ & 33.48 & 2.0 & 42.00 & 1.63 \\
\hline $58-59$ & 33.58 & 0.0 & 0.00 & 0.00 \\
\hline $68-69$ & 33.68 & 2.5 & 44.09 & 1.65 \\
\hline $78-79$ & 33.78 & 2.0 & 47.43 & 1.69 \\
\hline $88-89$ & 33.88 & 1.0 & 20.23 & 1.33 \\
\hline $98-99$ & 33.98 & 2.0 & 50.01 & 1.71 \\
\hline $108-109$ & 34.08 & 2.0 & 112.43 & 2.05 \\
\hline $118-119$ & 34.18 & 2.5 & 47.81 & 1.69 \\
\hline $128-129$ & 34.28 & 2.5 & 74.62 & 1.88 \\
\hline $138-139$ & 34.38 & 2.5 & 122.24 & 2.09 \\
\hline $148-149$ & 34.48 & 2.0 & 49.26 & 1.70 \\
\hline \multicolumn{5}{|l|}{ 130-806B-4H-7, } \\
\hline $8-9$ & 34.58 & 3.0 & 89.48 & 1.96 \\
\hline $18-19$ & 34.68 & 0.0 & 0.00 & 0.00 \\
\hline $28-29$ & 34.78 & 2.5 & 61.67 & 1.80 \\
\hline $48-49$ & 34.98 & 1.5 & 28.98 & 1.48 \\
\hline $58-59$ & 35.08 & 2.0 & 46.02 & 1.67 \\
\hline $73-74$ & 35.25 & 2.0 & 74.17 & 1.88 \\
\hline
\end{tabular}

Notes: Preservation index is $1=$ poor, $2=$ moderate, and $3=\operatorname{good}$. Abundance inde $x=\log (x / 1000+1)$ to large specimens $(>60 \mu \mathrm{m})$. Diameters range from 15 and $110 \mu \mathrm{m}$, with an average of about $40 \mu \mathrm{m}$. The number of areolae varies little, from about five to six areolae in $10 \mu \mathrm{m}$ in most of the smaller specimens to four areolae in $10 \mu \mathrm{m}$ in most of the larger specimens. In some cases, the larger and coarser specimens corresponded to Azpeitia barronii G. Fryxell and T.P. Watkins when seen with the SEM (see Fryxell et al., 1986; Sims et al., 1989).

The greatest dominance of small valves was observed for glacial intervals - the highest ratio values were observed in Samples 130$806 \mathrm{~B}-1 \mathrm{H}-1,127-128 \mathrm{~cm}$ (1.27 mbsf), $-1 \mathrm{H}-2,18-19 \mathrm{~cm}$ (1.68 mbsf), $-2 \mathrm{H}-1,58-59 \mathrm{~cm}$ (7.08 mbsf), and $-2 \mathrm{H}-1,78-79 \mathrm{~cm}$ (7.28 mbsf), which correspond to oxygen isotope Stages 2,4 , and 10 , respectively. Large forms were not seen in these samples (Fig. 5). A high ratio $(26.6 \%$ small $/ 1.9 \%$ large $=14)$ also was found for Sample 130-806B$1 \mathrm{H}-2,78-79 \mathrm{~cm}$ (2.28 mbsf; oxygen isotope Substage 5c). Small specimens of $A$. nodulifera are abundant in all samples, making up more than $40 \%$ of the diatom assemblage everywhere. Large specimens $(>60 \mu \mathrm{m})$, on the other hand, are less abundant and they never represent more than $20 \%$ of the total. Therefore, low ratios of $<1$ were not observed. A sample with large forms only was never observed.

We also noted size variations in the species Hemidiscus cuneiformis (Plate 1, Figs. 7-8), although not as regular as in A. nodulifera. However, an increased number of larger forms of $>150 \mu \mathrm{m}$ in length were recorded in those samples with abundant large specimens of $A$. nodulifera.

Variations in the valve outline of Roperia tesselata, from round to oval to oval-teardrop shapes, were recorded. The round-shaped specimens are the most abundant ones of the three shapes (Plate 1, Figs. 4-6). We did not find any relationship between the different shapes and the glacial and interglacial periods during the Pleistocene. Variations in size and shape of this species were reported earlier by several other authors (e.g., Fryxell et al., 1986; Lee and Lee, 1990, and references therein).

\section{DISCUSSION}

Fourier expansion of the diatom abundance record demonstrates the presence of cycles related to eccentricity and obliquity (Fig. 4). Comparison of Fourier spectra of the diatom abundance record and the $\delta^{18} \mathrm{O}$ record of $G$. sacculifer confirms this result (Fig. 6) and suggests that there is power related to precessional forcing as well (near 24 and $18 \mathrm{ka}$, close to the expected periods of 23 and $19 \mathrm{ka}$ ). This precessional sensitivity of the diatom record contrasts with a lack of precessional power in the $\delta^{18} \mathrm{O}$ record. Cyclicity also is concentrated near $62 \mathrm{ka}$ in the diatom record, without a corresponding cyclicity in the oxygen isotopes (harmonics 26 and 27, Fig. 6). The source of this periodicity is unknown; it may represent an interference phenomenon, as it is close to both the difference ( $100-41 \mathrm{ka})$ and to the $\operatorname{sum}(41+19 \mathrm{ka} ; 41+23 \mathrm{ka})$ of astronomical frequencies. A large amount of noise is present in the diatom record at high frequencies, suggesting great sensitivity to disturbance on short time scales. Shortlived barren intervals (i.e., downward spikes) probably contribute substantially to this phenomenon.

The stratigraphy of the phase relationship between the diatom abundance record and the $\delta^{18} \mathrm{O}$ record of $G$. sacculifer within the eccentricity and obliquity windows is shown in Figure 7. On the whole, cycles are nicely in phase, with high sea level (interglacials) linked to high diatom abundance, and low sea level (glacials) to low abundance. The phase shifts have a different sense for eccentricity and obliquity. For eccentricity, phase shifts (within pre-Kolbe time) suggest higher abundances during the onset of cooling, whereas for phase shifts in the obliquity window (late within the Kolbe epoch) there is an indication that diatom abundance increases during deglaciation.

Numerous studies (Arrhenius, 1952; Kolbe, 1954; Burckle and McLaughlin, 1977; Murray and Schrader, 1982; Burckle et al., 1981; Bromble and Burckle, 1983) propose that increased nutrient supply to the surface waters (upwelling conditions) or water mass fluctua- 

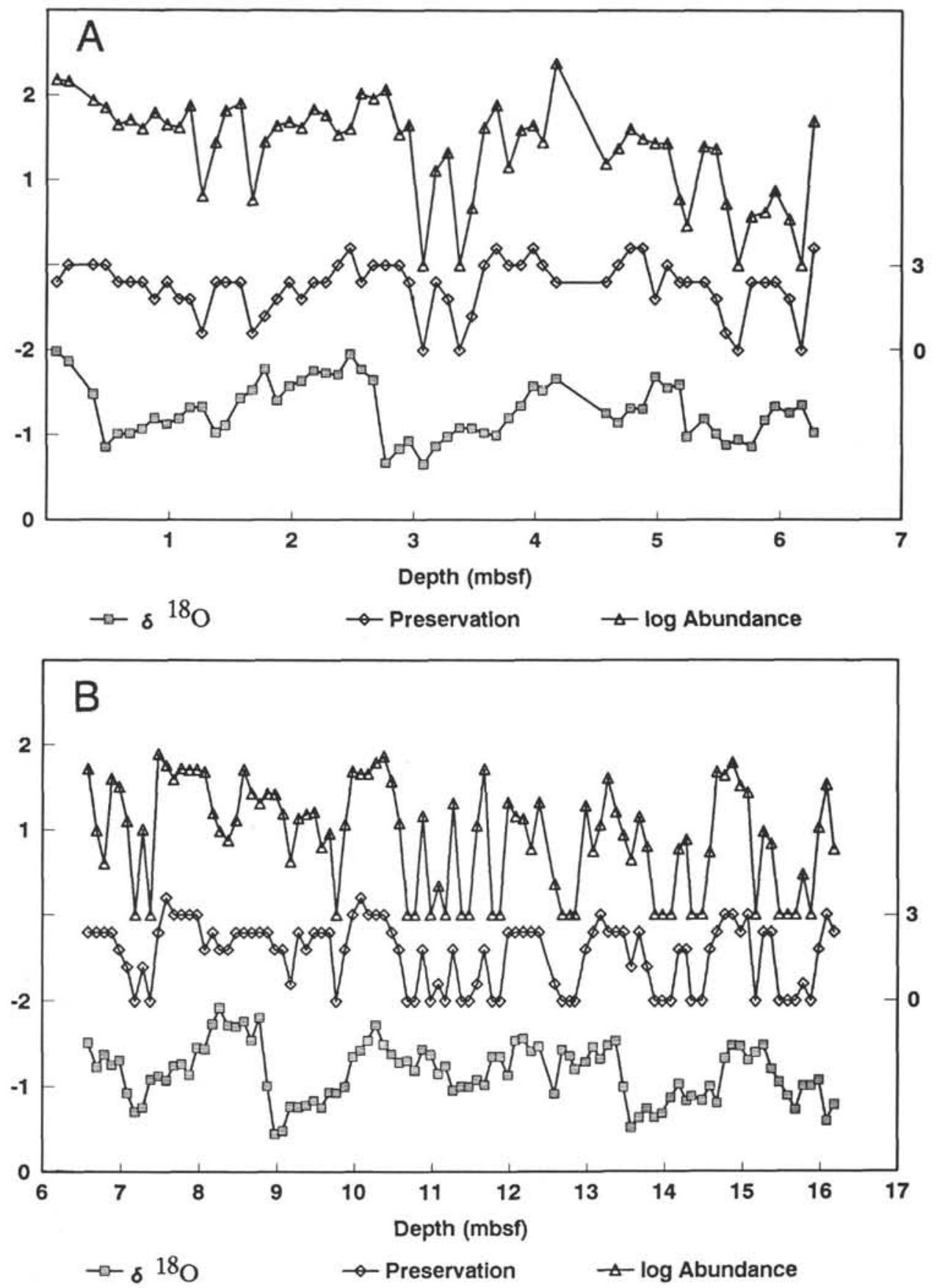

Figure 1. Fluctuations in diatom abundance $[\operatorname{as} \log (x / 1000+1)]$, preservation (from $0=$ no preservation to $3=$ good), and the $\delta^{18} \mathrm{O}$ record in Cores 130-806B-1H (A), 130-806B-2H (B), 130-806B-3H (C), and 130-806B-4H (D). $\delta^{18} \mathrm{O}$ data from Berger et al. (this volume).

tions affect the size distribution of Azpeitia nodulifera as recorded in the sediments of the eastern equatorial Pacific. Arrhenius (1952) noted rhythmical downcore fluctuations in the size distribution of this species, and suggested that they may be related to changes in the circulation of the equatorial system during the Pleistocene: an increase in the number of large specimens was related to the beginning of glacial periods (see also Kolbe, 1954). On the other hand, Burckle et al. (1981) and Bromble and Burckle (1983) reported that an increase in size of $A$. nodulifera specimens (ratio $<60$ to $>60 \mu \mathrm{m}$ ) could be used to identify oxygen isotope Stages 1,3 , and 5 , and that Stages 2,4 , and 6 were characterized by small
A. nodulifera. Our findings in this respect are similar to those of Burckle et al. (1981).

On a north-south traverse across the equator and east of $140^{\circ} \mathrm{W}$, Burckle and McLaughlin (1977) observed a strong unimodal distribution (at about $40 \mu \mathrm{m}$ ) north of $4^{\circ} \mathrm{N}$ and a bimodal distribution (40 and $>70 \mu \mathrm{m}$ ) between the equator and $3^{\circ} \mathrm{N}$. Burckle assumed that two populations existed, with smaller forms living close to the surface of the ocean and being associated with a shallow mixed layer, whereas larger forms were characterized as deeper living (though still in the photic zone) and related to a deep mixed layer (L.H. Burckle, pers. comm.). Bimodal (or multimodal) distributions are thought to indi- 

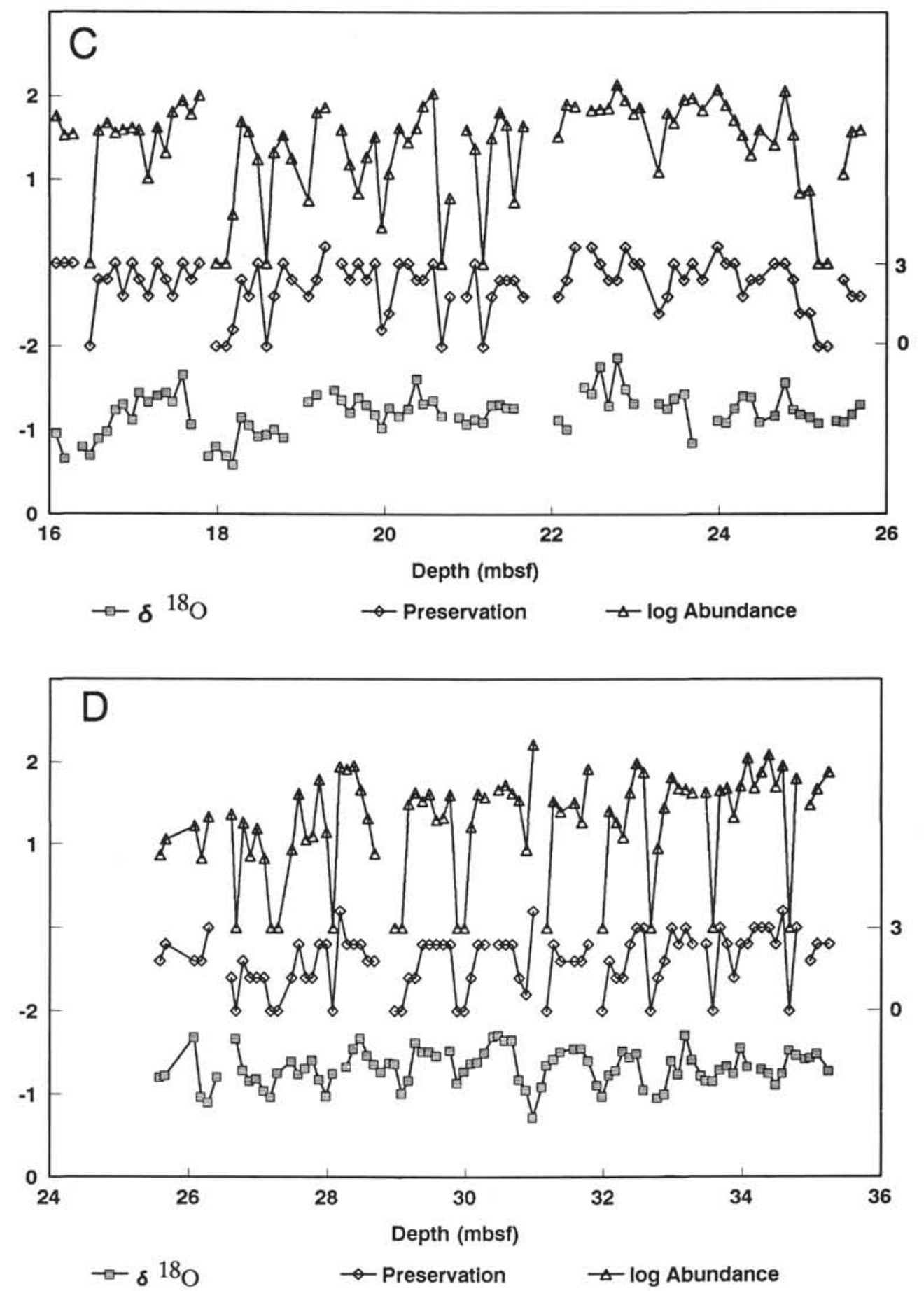

Figure 1 (continued).

cate that a population is not uniform but consists of two or more genotypic units, where one or the other type may reach a stronger development without complete suppression of the other (Kolbe, 1954). Another interpretation is the hypothesis that the improvement of life conditions for a species during certain periods may result in an increased production of auxospores, which in turn leads to high production of large cells. (Auxospore formation is a way of restoring maximum cell size for a given species, after repeated asexual fission has led to steadily decreasing cell size in successive generations).

Intervals barren of diatoms, or with low abundance values, raise questions about the possibility of accelerated growth of diatoms during glacials. Martin et al. (1989) observed that diatoms in the Gulf of Alaska, when growing rapidly (e.g., from the addition of iron to the growth medium), may not secrete thick frustules (see also Calvert, 1966). Productivity was increased during glacial time in the region studied here (Herguera and Berger, 1991). Thus, diatoms may have grown faster and built less silicified frustules, which were subsequently readily dissolved on the seafloor. Alternatively, or in addition, there was a depletion of silica in the thermocline during glacials (see Berger and Wefer, 1991, and references therein).

Our results contrast with observations in the eastern equatorial Pacific. Lyle et al. (1988) studied the record of opal accumulation in 

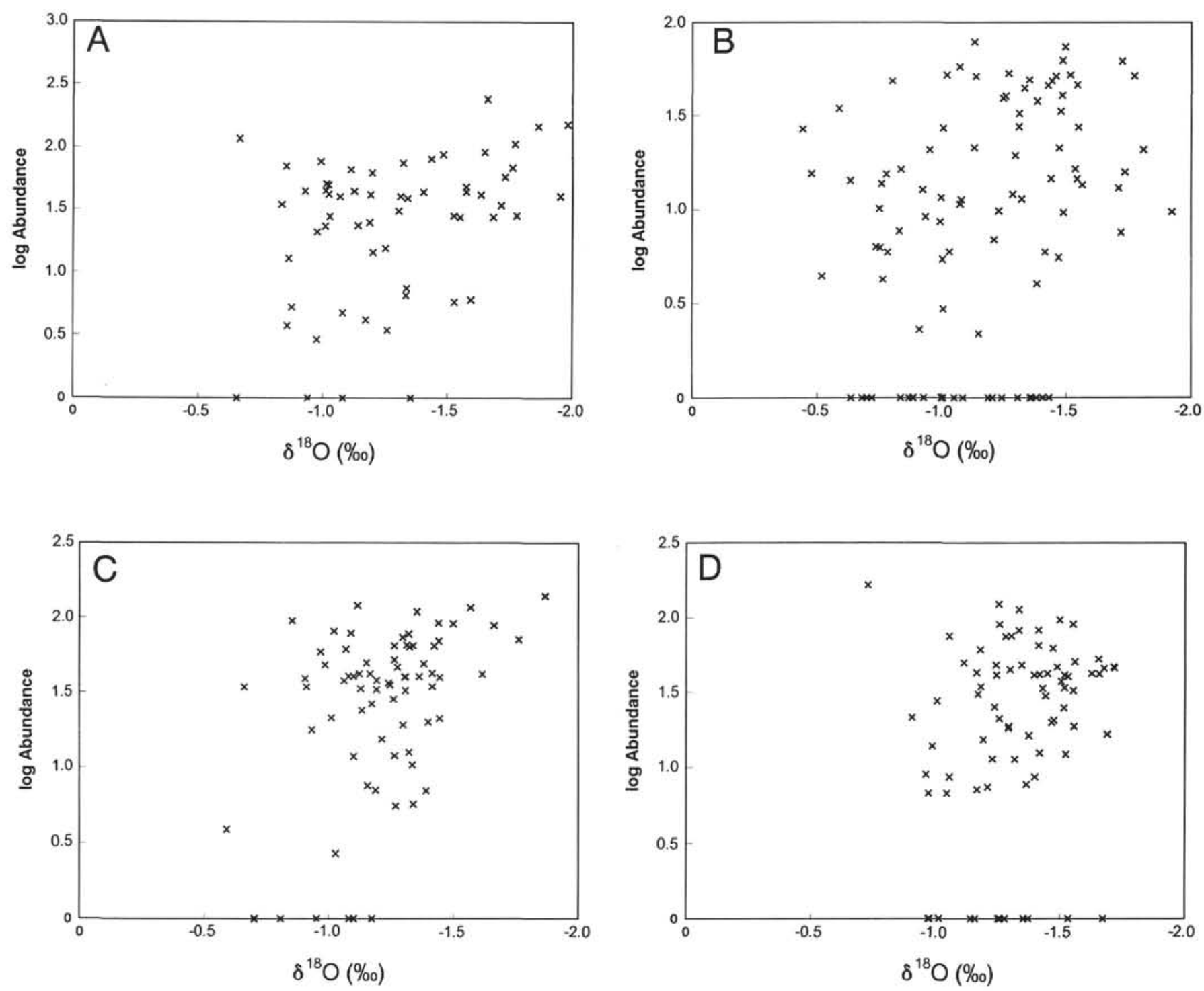

Figure 2. Diatom abundance index ( $y$-axis) vs. $\delta^{18} \mathrm{O}$ signal of $G$. sacculifer ( $x$-axis) in Cores 130-806B-1H (A), 130-806B-2H (B), 130-806B-3H (C), and 130-806B-4H (D).

that region for the last $300 \mathrm{k.y}$. Their data show a strong association between accumulation rates of organic carbon and opal, suggesting that production of opal (and not its preservation) dominates the signal. In detail, however, there are interesting discrepancies (e.g., the opal spike at $10-15 \mathrm{ka}$, when Corg is dropping) that possibly point to preservational effects decoupled from productivity. To explain differences in the patterns of carbonate and opal accumulation, Lyle et al. (1988) proposed the existence of two partially exclusive plankton communities: one highly productive of opal (rich in diatoms and radiolarians), and another rich in calcite producers (coccolithophorids and foraminifers).

A depletion of silica in the thermocline during glacial times could have resulted from a number of factors, for example, from increased efficiency of the export of silica frustules in the equatorial upwelling system and elsewhere and increased burial of opal in continental margins. Also, a decrease in the export of dissolved silicate from the Atlantic, that is, a relaxation of basin-basin fractionation caused by a decrease in the delivery of deep water from the Atlantic (Shackleton et al., 1983), should have had the effect of decreasing the silicate content in the deep Pacific.
In general, the diatom assemblages of the western equatorial Pacific are poorly preserved compared with the east Pacific and dominated by the solution-resistant species Azpeitia nodulifera (recorded as Coscinodiscus nodulifer by Mikkelsen, 1978). Thus, in a comparison of the preservational states along the equator, from east to west, preservation is positively correlated with productivity. However, the results presented here show that this correlation cannot be used for reconstruction of productivity through time; there is a pronounced difference between the relatively poorly preserved flora at intervals deposited during glacial periods and the much better preserved assemblages deposited during interglacials (also Lange and Berger, 1991). These results agree well with those of Mikkelsen (1978), who observed an improvement in diatom preservation from glacial through Holocene sediment sequences (ERDC cores) during the last $20,000 \mathrm{yr}$. It appears, then, that the increased productivity during the last glacial (and presumably during earlier glacials) did not result in improved preservation of diatoms in the sediment, and that the present geographic pattern cannot be translated into stratigraphic patterns in the usual Lyellian manner. 


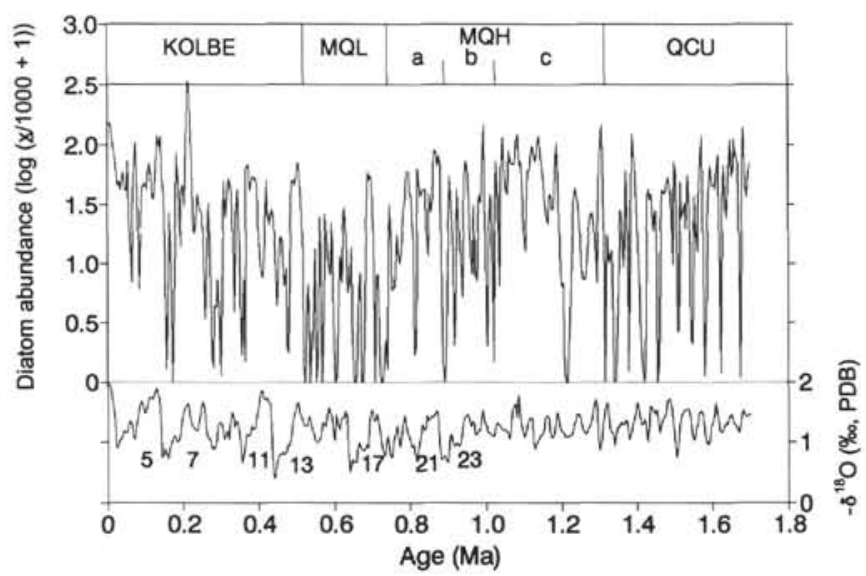

Figure 3. Diatom abundance index (interpolated) in the upper $35.25 \mathrm{~m}$ of Hole 806B. Age model and oxygen isotope stratigraphy from Berger et al. (this volume). Diatom abundance stratigraphy intervals are the Kolbe interval $(=$ late Quarternary high-abundance epoch), MQL = mid-Quarternary low, $\mathrm{MQH}$ $=$ mid-Quarternary high, and QCU = early Pleistocene cyclic unit. Emiliani stage numbers as given in Shackelton and Opdyke $(1973,1976)$ for orientation.

\section{ACKNOWLEDGMENTS}

We are greatly indebted to L.H. Burckle and J.A. Barron for helpful comments and review of the manuscript. We thank J. Baldauf, J.A. Barron, D. Bukry, and A. Sanfilippo for fruitful discussions during the early stages of this work, and especially L.H. Burckle for sharing unpublished data with us; Huy Tran for sample preparation; and the Captain and crew and ODP technicians on board the JOIDES Resolution during Leg 130 for their skills in sediment collection and help throughout the endless days and nights of the cruise. This work was supported by ODP Grant No. 20466. Special thanks to G. Wefer, who read the manuscript and kindly permitted use of unpublished oxygen isotope data generated in Bremen.

\section{REFERENCES}

Arrhenius, G., 1952. Sediment cores from the east Pacific. Rep. Swed. DeepSea Exped. 1947-1948, 5:1-288.

Barron, J.A., 1989. The late Cenozoic stratigraphic record and hiatuses of the northeast Pacific: results from the Deep Sea Drilling Project. In Winterer, E.L., Hussong, D.M., and Decker, R.W. (Eds.), The Eastern Pacific Ocean and Hawaii (Vol. N). Geol. Soc. Am., 311-322.

Barron, J.A., and Baldauf, J.G., 1989. Tertiary cooling steps and paleoproductivity as reflected by diatoms and biosiliceous sediments. In Berger, W.H., Smetacek, V.S., and Wefer, G. (Eds.), Productivity of the Ocean: Present and F ast: Chichester (Wiley-Interscience), 341-354.

Berger, W.H., 1970. Biogenous deep-sea sediments: fractionation by deep-sea circulation. Geol. Soc. Am. Bull., 81:1385-1402.

, 1976. Biogenous deep sea sediments: production, preservation and interpretation. In Riley, J.P., and Chester, R. (Eds.), Chemical Oceanography (Vol. 5, 2nd ed.): London (Academic Press), 265-388.

Berger, W.H., and Herguera, J.C., 1992. Reading the sedimentary record of the ocean's productivity. In Falkowski, P.G., and Woodhead, A.D. (Eds.), Primary Productivity and Biogeochemical Cycles in the Sea: New York (Plenum), 455-486.

Berger, W.H., and Wefer, G., 1991. Productivity of the glacial ocean: discussion of the iron hypothesis. Limnol. Oceanogr., 36:1899-1918.

Boltovskoy, D., 1989. Radiolarian record of the last 40,000 years in the western equatorial Pacific. Oceanol. Acta, 12:79-86.

Bromble, S.L., and Burckle, L.H., 1983. A late Quaternary stratigraphy for DSDP Site 480, Gulf of California. Mar. Micropaleontol., 7:541-543.

Burckle, L.H., and McLaughlin, R.B., 1977. Size changes in the marine diatom Coscinodiscus nodulifer A. Schmidt in the equatorial Pacific. Micropaleontology, 23:216-222.
Burckle, L.H., Shackleton, N.J., and Bromble, S.L., 1981. Late Quaternary stratigraphy for the equatorial Pacific based upon the diatom Coscinodiscus nodulifer. Micropaleontology, 27:352-355.

Calvert, S.E., 1966. Accumulation of diatomaceous silica in sediments of the Gulf of California. Geol. Soc. Am. Bull., 77:569-596.

1974. Deposition and diagenesis of silica in marine sediments. In Hsü, K.J., and Jenkyns, H. (Eds.), Pelagic Sediments on Land and Under the Sea. Spec. Publ. Internat. Assoc. Sedimentol., 1:273-299.

, 1983. Sedimentary geochemistry of silicon. In Aston, S.R. (Ed.), Silicon Geochemistry and Biogeochemistry: London (Academic Press), 143-186.

DeMaster, D.J., 1981. The supply and accumulation of silica in the marine environment. Geochim. Cosmochim. Acta, 45:1715-1732.

Diester-Haass, L., 1978. Sediments as indicators of upwelling. In Boje, R., and Tomczak, M., (Eds.), Upwelling Ecosystems: Heidelberg (Springer-Verlag), 261-281.

Fryxell, G.A., Sims, P.A., and Watkins, T.P., 1986. Azpeitia (Bacillariophyceae): related genera and promorphology. Syst. Bot. Monogr., 13:1-74.

Heath, G.R., 1974. Dissolved silica and deep-sea sediments. In Hay, W.W. (Ed.), Studies in Paleo-Oceanography. Spec. Publ.-Soc. Econ. Paleontol. Mineral., 20:77-93.

Herguera, J.C., 1992. Deep-sea benthic foraminifera and biogenic opal: glacial to postglacial productivity changes in the western equatorial Pacific. Mar. Micropaleontol., 79-98.

Herguera, J.C., and Berger, W.H., 1991. Paleoproductivity from benthic foraminifera abundance: glacial to postglacial change in the west-equatorial Pacific. Geology, 19:1173-1176.

Imbrie, J., Hays, J.D., Martinson, D.G., McIntyre, A., Mix, A.C., Morley, J.J., Pisias, N.G., Prell, W.L., and Shackleton, N.J., 1984. The orbital theory of Pleistocene climate: support from a revised chronology of the marine $\delta^{18} \mathrm{O}$ record. In Berger, A.L. (Ed.), Milankovitch and Climate (Pt. 1): Dordrecht (D. Reidel), 269-305.

Johnson, T.C., 1974. The dissolution of siliceous microfossils in surface sediments of the eastern tropical Pacific. Deep-Sea Res., Pt. A, 21:851-864.

Kolbe, R.W., 1954. Diatoms from the equatorial Pacific cores. Rep. Swed. Deep-Sea Exped. 1947-1948, 6:1-49.

, 1955. Diatoms from equatorial Atlantic cores. Rep. Swed. Deep Sea Exped. 1947-1948, 7:150-184.

, 1957. Diatoms from equatorial Indian Ocean cores. Rep. Swed. Deep-Sea Exped. 1947-1948, 9:1-50.

Kroenke, L.W., Berger, W.H., Janecek, T.R., et al., 1991. Proc. ODP, Init. Repts., 130: College Station, TX (Ocean Drilling Program).

Lange, C.B., and Berger, W.H., 1991. Diatoms fail to indicate the increased glacial productivity in the western equatorial Pacific. Ann. Meet. Geol. Soc. Am. Abstr. A107.

Lange, C.B., Burke, S.K., and Berger, W.H., 1990. Biological production off Southern California is linked to climatic change. Clim. Change, 16:319-329.

Lee, J.H., and Lee, J.Y., 1990. A light and electron microscopic study on the marine diatom Roperia tesselata (Roper) Grunow. Diatom Res., 5:325-335.

Leinen, M., 1979. Biogenic silica accumulation in the central equatorial Pacific and its implications for Cenozoic paleoceanography. Geol. Soc. Am. Bull., 90:1310-1376.

Leinen, M., Cwienk, D., Heath, G.R., Biscaye, P., Kolla, V., Thiede, J., and Dauphin, J.P., 1986. Distribution of biogenic silica and quartz in recent deep-sea sediments. Geology, 14:199-203.

Lisitzin, A.P., 1972. Sedimentation in the world ocean. Spec. Publ.-Soc. Econ. Paleontol. Mineral., 17:1-128.

Lyle, M., Murray, D.W., Finney, B.P., Dymond, J., Robbins, J.M., and Brooksforce, K., 1988. The record of late Pleistocene biogenic sedimentation in the eastern tropical Pacific Ocean. Paleoceanography, 3:39-59.

Martin, J.H., Gordon, R.M., Fitzwater, S., and Broenkow, W.W., 1989. VERTEX: phytoplankton/iron studies in the Gulf of Alaska. Deep-Sea Res., Pt. A, 36:649-680.

Mikkelsen, N., 1978. Preservation of diatoms in glacial to Holocene deep-sea sediments of the equatorial Pacific. Geology, 6:553-555.

Milliman, J.D., and Takahashi, K., in press. Carbonate and opal production and accumulation in the ocean. In Usselman, T.M., Hay, W., and Meybeck, M. (Eds.), Global Surficial Geofluxes: Modern to Glacial: Washington, DC (National Acad. Press).

Murray, D., and Schrader, H.J., 1982. The size distribution of the centric diatom Coscinodiscus nodulifer, Site 480, Guaymas Basin slope, Gulf of California, In Curray, J.R., Moore, D.G., et al., Init. Repts. DSDP, 64: Washington (U.S. Govt. Printing Office), 1239-1244. 
Pisias, N.G., 1976. Late Quaternary sediment of the Panama Basin: sedimentation rates, periodicities, and controls of carbonate and opal accumulation. Mem.-Geol. Soc. Am., 145:375-391.

Pisias, N.G., and Rea, D.K., 1988. Late Pleistocene paleoclimatology of the central equatorial Pacific: sea surface response to the southeast trade winds. Paleoceanography, 3:21-37.

Romine, K., 1982. Late Quaternary history of atmospheric and oceanic circulation in the eastern equatorial Pacific. Mar. Micropaleontol., 7:163-187.

Sancetta, C., and Calvert, S.E., 1988. The annual cycle of sedimentation in Saanich Inlet, British Columbia: implications for the interpretation of diatom fossil assemblages. Deep-Sea Res., Pt. A, 35:71-90.

Schrader, H.J., and Gersonde, R., 1978. Diatoms and silicoflagellates. Utrecht Micropaleontol. Bull., 17:129-176.

Shackleton, N.J., Imbrie, J., and Hall, M., 1983. Oxygen and carbon isotope record of east Pacific Core V19-30: implications for the formation of deep water in the Late Pleistocene North Atlantic. Earth Planet. Sci. Lett., 65:233-266.

Shackleton, N.J., and Opdyke, N.D., 1973. Oxygen isotope and paleomagnetic stratigraphy of Equatorial Pacific Core V28-238: oxygen isotope temperatures and ice volumes on a $10^{5}$ year and $10^{6}$ year scale. Quat. Res., 3:39-55.
1976. Oxygen-isotope and paleomagnetic stratigraphy of Pacific Core V28-239: late Pliocene to latest Pleistocene. In Cline, R.M., and Hays, J.D. (Eds.), Investigations of Late Quaternary Paleoceanography and Paleoclimatology. Mem.-Geol. Soc. Am., 145:449-464.

Sims, P., Fryxell, G.A., and Baldauf, J.G., 1989. Critical examination of the diatom genus Azpeitia: species useful as stratigraphic markers for the Oligocene and Miocene epochs. Micropaleontology, 35:293-307.

Suess, E., and Thiede, J. (Eds.), 1983. Coastal Upwelling: Its Sedimentary Record. Pt. A: Responses of the Sedimentary Regime to Present Coastal Upwelling: New York (Plenum).

Thiede, J., and Suess, E. (Eds.), 1983. Coastal Upwelling: Its Sedimentary Record. Pt. B: Sedimentary Records of Ancient Coastal Upwellings: New York (Plenum).

\section{Date of initial receipt: 18 October 1991 \\ Date of acceptance: 1 September 1992 \\ Ms 130B-011}

A

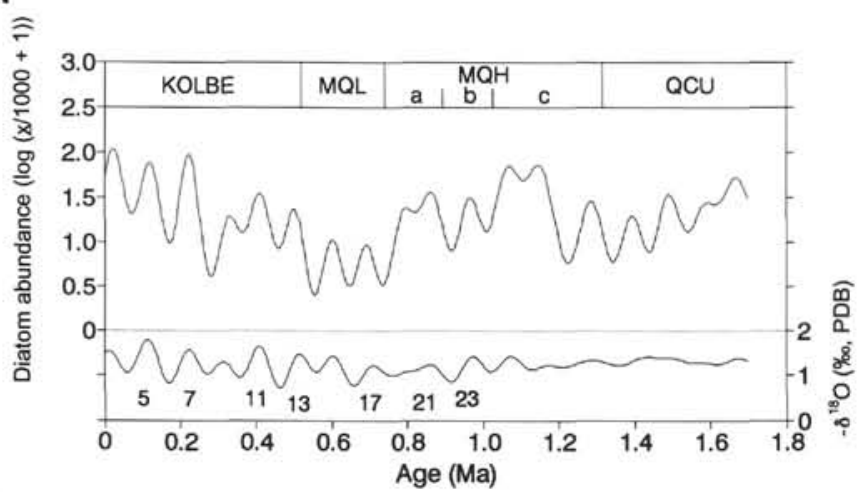

C

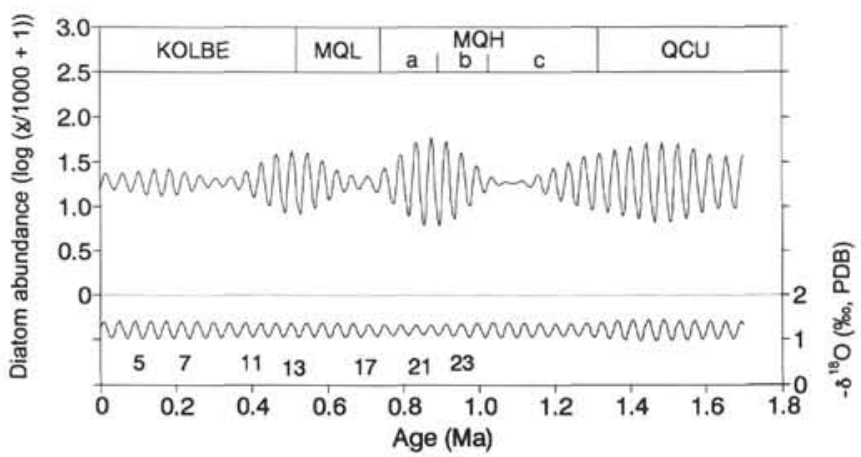

B

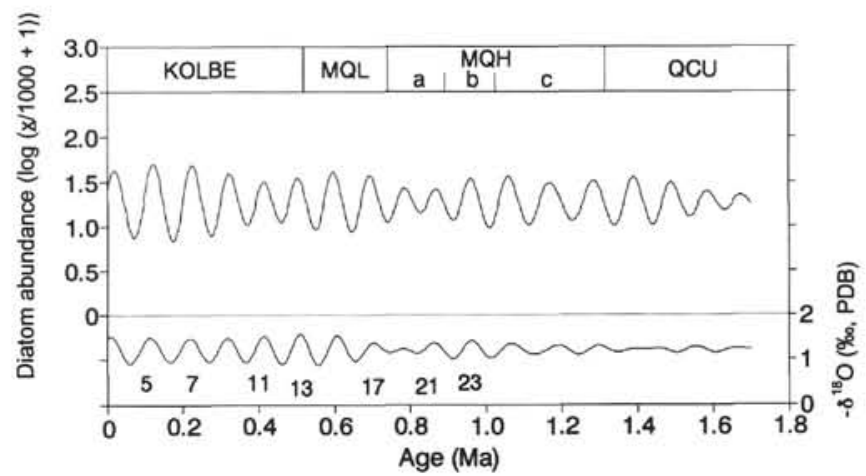

\section{D}

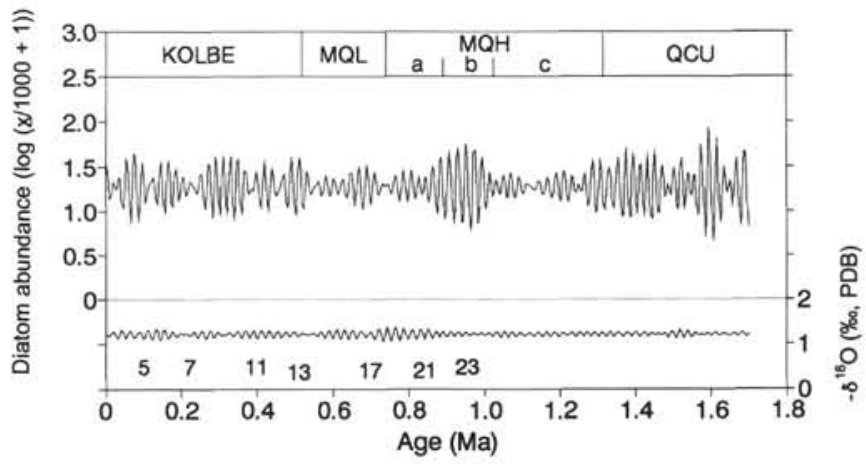

Figure 4. Fourier analysis of diatom abundance record. Vertical lines in Figures 4A-4D are arbitrary boundaries between the diatom abundance intervals defined here (see text and Fig. 3). A. Fourier fit, using the harmonics for periods $>89 \mathrm{ka}$. This curve contains the information for eccentricity and longer waves. B. Eccentricity-related component; sum of terms between 87 and 117 k.y. C. Obliquity-related component; window is from 36 to 47 k.y. D. Precession-related component; window is from 18 to 24 k.y. For orientation, the oxygen isotope record in the respective window appears at the bottom of the figure. Stage numbers as in Figure 3. 
A

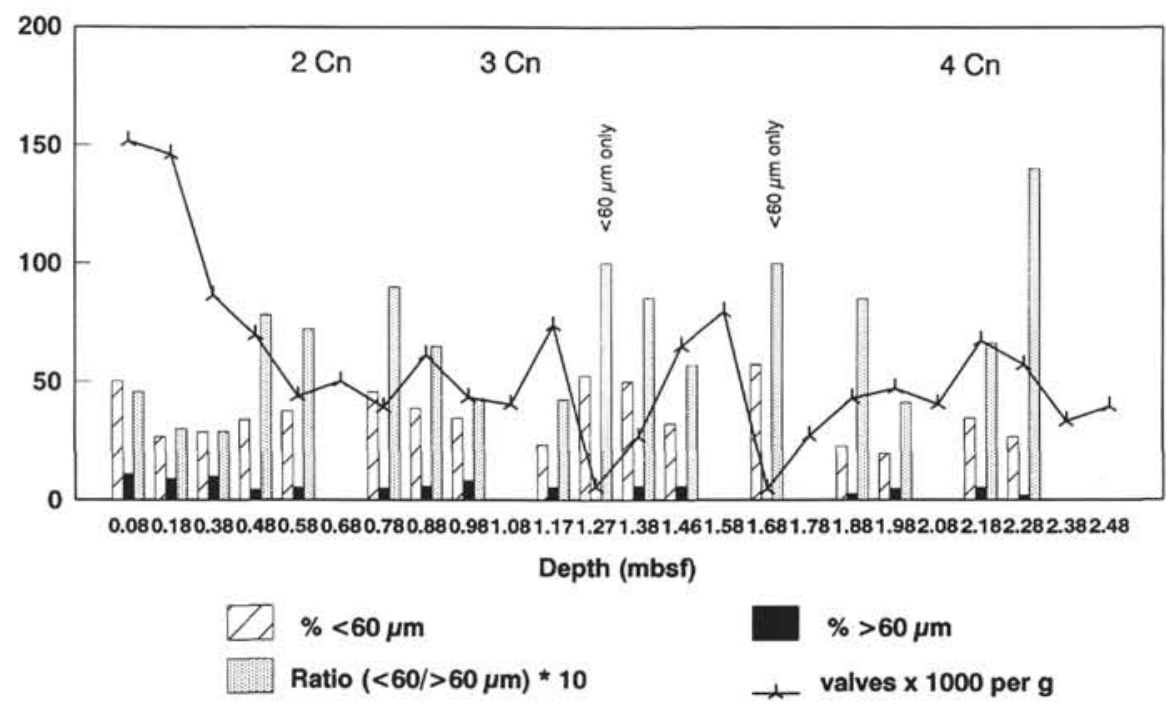

B

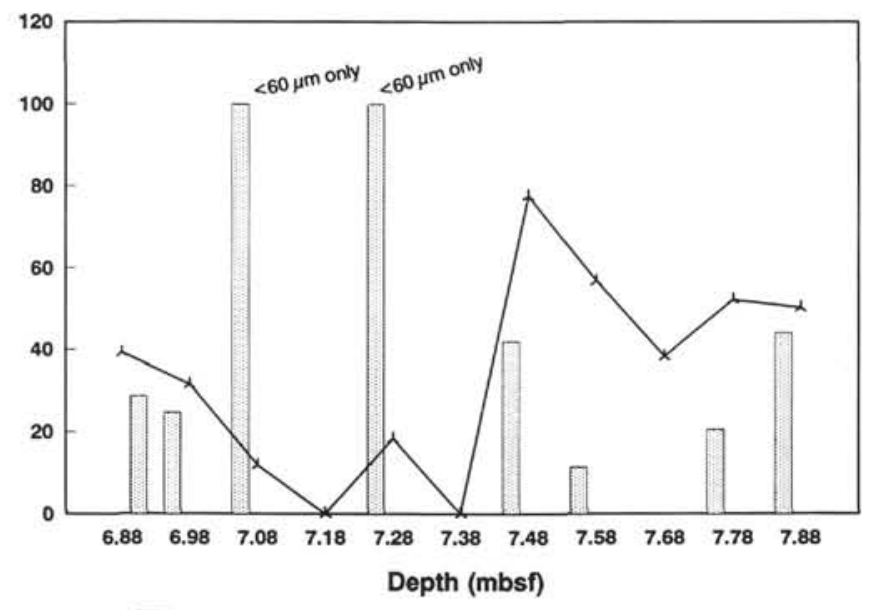

Ratio $(<60 />60 \mu \mathrm{m}) \star 10 \nrightarrow$ valves $\times 1000$ per $\mathrm{g}$

Figure 5. Percent Azpeitia nodulifera vs. total valves. A. nodulifera size distributions for the intervals $0-2.5$ mbsf (A) and 6.8-8.0 mbsf (B). A. nodulifera size scale is given as the ratio of small to large valves. The total number of diatom valves per gram of dry sediment is shown. Samples lacking specimens over $60 \mu \mathrm{m}$ in diameter (ratio $=\infty$ ) are marked with " $<60 \mu \mathrm{m}$ only." The labels $2 \mathrm{Cn}, 3 \mathrm{Cn}$, and $4 \mathrm{Cn}$ in Figure 5A refer to the late Quaternary stratigraphy of Burckle et al. (1981) for the eastern equatorial Pacific, based upon size changes of $A$. nodulifera, shown here for comparison. These labels indicate high ratios $(<60 />60 \mu \mathrm{m})$ for $2 \mathrm{Cn}$ and $4 \mathrm{Cn}$, and lower values for $3 \mathrm{Cn}$ (see Burckle et al., 1981; Bromble and Burckle, 1983). 


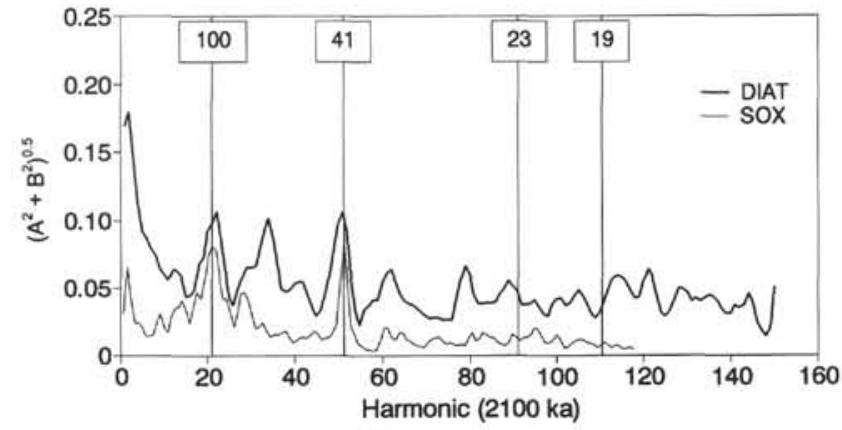

Figure 6. Comparison of Fourier spectrum of diatom abundance index (DIAT, upper line) with that of $\delta^{18} \mathrm{O}$ in $G$. sacculifer (SOX, lower line). Each spectrum was smoothed with a triangle filter (1-2-1). Vertical lines refer to eccentricity (100), obliquity (41), and precession (23 and 19).

A

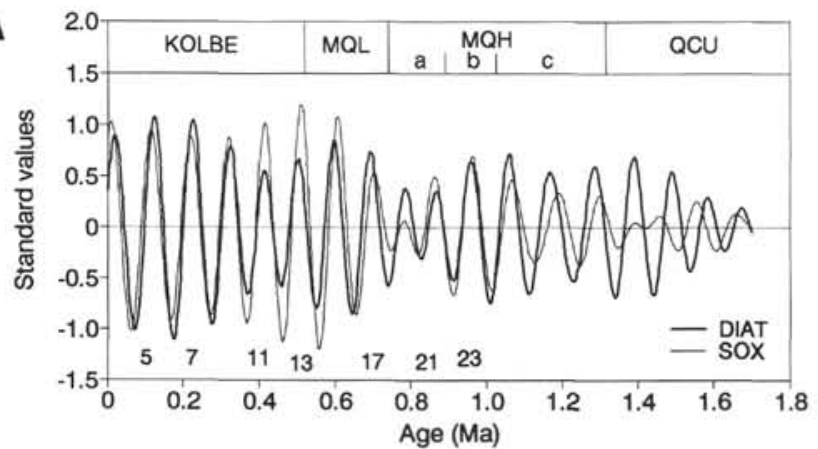

B

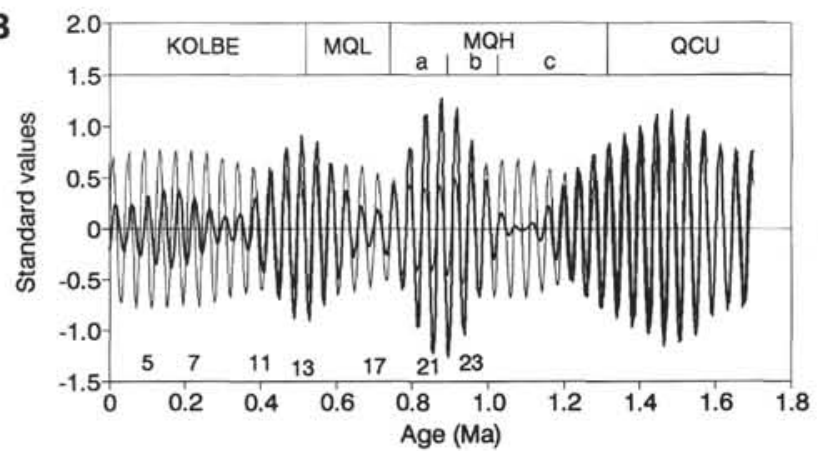

Figure 7. Comparison of orbital components of diatom abundance (DIAT) and $-\delta^{18} \mathrm{O}$ in $G$. sacculifer (SOX), using standardized values, to show change in amplitude and phase relationships. Standard values are demeaned and divided by twice the standard deviation. Isotopic stages are given for references. A. Eccentricity-related components. B. Obliquity-related components. 

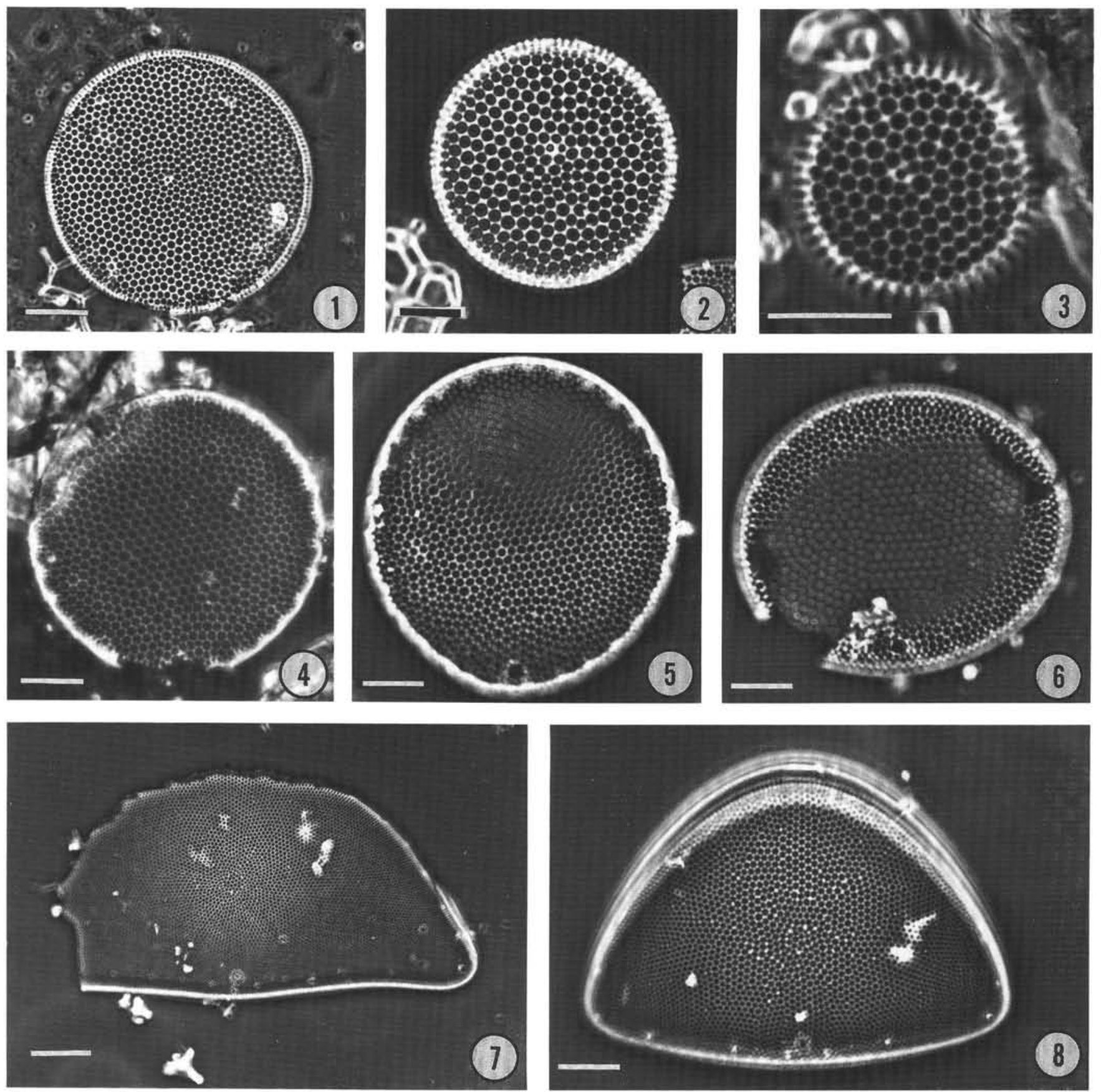

Plate 1. Diatoms from Hole 806B, LM. 1-3. Azpeitia nodulifera (A. Schmidt) G. Fryxell et P.A. Sims. Size variations. (1) Sample 130-806B-1H-1, 58-59 cm. (2) Sample 130-806B-1H-3, 58-59 cm. (3) Sample 130-806B-1H-1, 48-49 cm. 4-6. Roperia tesselata (Roper) Grunow. Variations of valve outline. (4) Sample 130-806B-3H-5, 48-49 cm. (5) Sample 130-806B-1H-3, 68-69 cm. (6) Sample 130-806B-2H-7, 58-59 cm. Specimens with circular valves are present throughout; oval and oval-teardrop shapes occur in "pulses." 7-8. Hemidiscus cuneiformis Wallich in Sample 130-806B-1H-4, 88-89 cm. (7) Broken specimen, approximately $160 \mu \mathrm{m}$ in length. Length is measured along the straight margin of the valve. Scale bars: 1,7 , and $8=20 \mu \mathrm{m} ; 2-6=10 \mu \mathrm{m}$. 

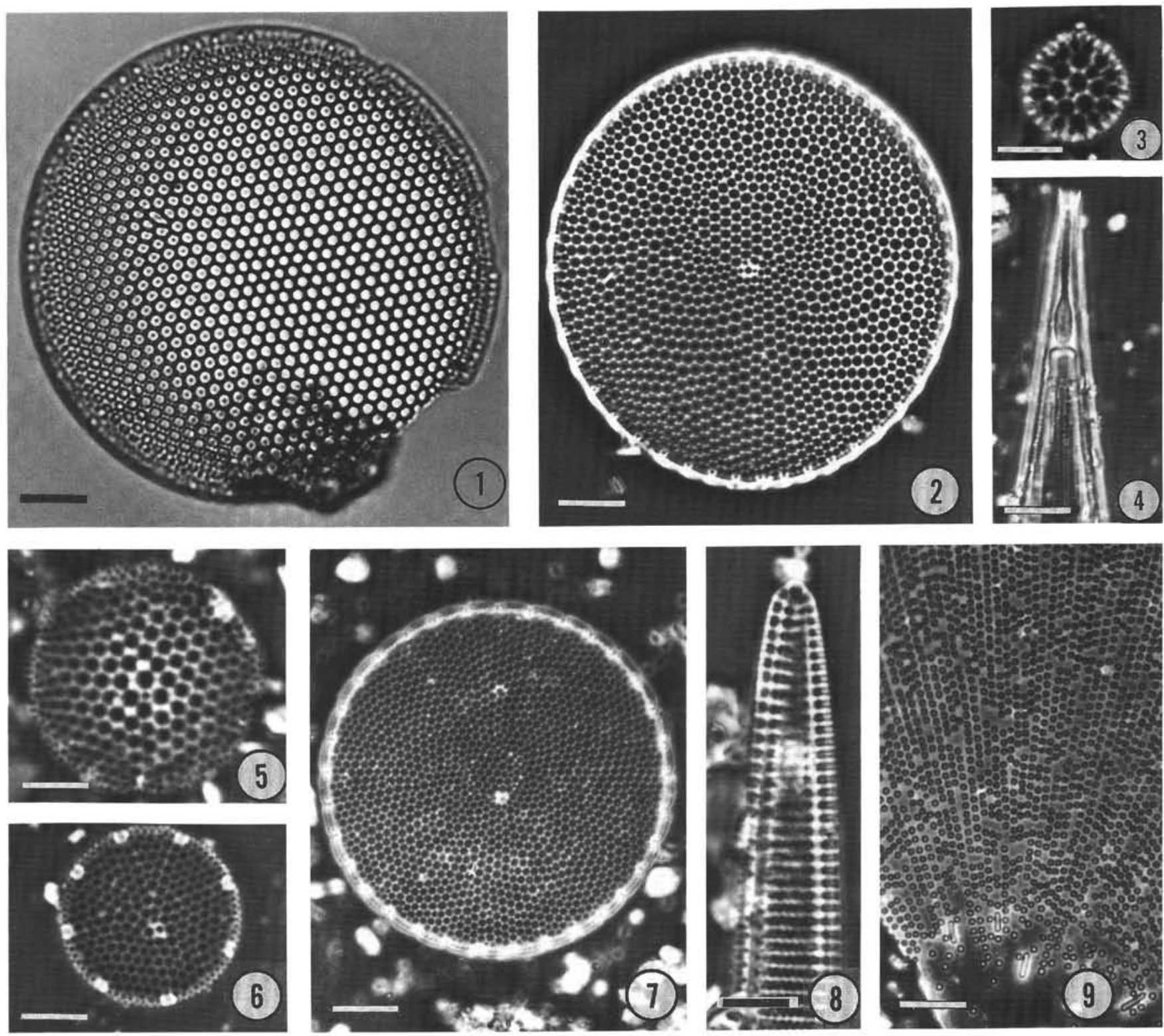

Plate 2. Diatoms from Hole 806B, LM. 1. Thalassiosira leptopus (Grunow) Hasle et G. Fryxell. Sample 130-806B-1H-4, 28-29 cm. 2. Azpeitia africana (Janish ex Schmidt) G. Fryxell et T.P. Watkins; Sample 130-806B-1H-4, 28-29 cm. 3. Thalassiosira oestrupii (Ostenfeld) Hasle var. oestrupii. Sample 130-806B-1H-1, 48-49 cm. 4. Rhizosolenia bergonii H. Peragallo. Distal part of theca. Sample 130-806B-3H-5, 28-29 cm. 5. Thalassiosira oestrupii var. venrickae G. Fryxell et Hasle. Sample 130-806B-1H-4, 38-39 cm. 6. Small specimen of Azpeitia neocrenulata (VanLandingham) G. Fryxell et T.P. Watkins. Sample 130-806B-2H-3,58-59 cm. 7. Azpeitia sp., $55 \mu \mathrm{m}$ in diameter, eight areolae in 10 $\mu \mathrm{m}$, central annulus and central labiate process. Sample 130-806B-3H-5, $28-29 \mathrm{~cm}$. Specimens assigned to this taxon resemble somewhat A. neocrenulata and A. africana. 8. Nitzschia marina Grunow. Only one apex shown. Sample 130-806B-1H-1, 18-19 cm. 9. Ethmodiscus gazellae (Janish ex Grunow) Hustedt. Fragment close to center of valve showing a central nonareolated area bordered by an irregular ring of processes of size $4 \mu \mathrm{m}$. Sample 130-806B-3H-5, 48-49 cm. Ethmodiscus spp. fragments common throughout. Scale bars: 1, 2, 4, 7, and 9 $=10 \mu \mathrm{m} ; 3,5,6$, and $8=5 \mu \mathrm{m}$. 

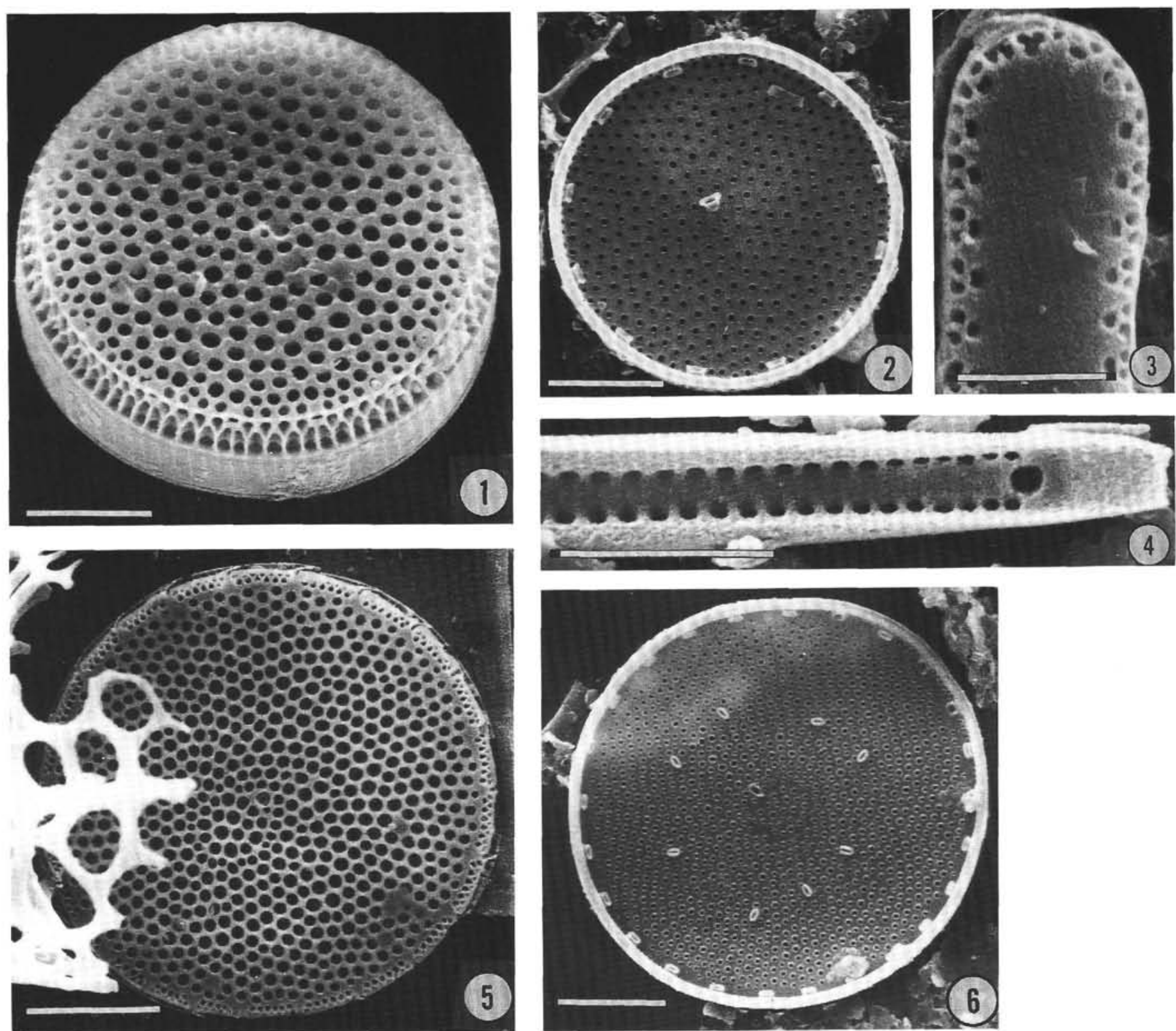

Plate 3. Diatoms from Hole 806B, SEM. 1. Whole frustule of Azpeitia nodulifera (A. Schmidt) G. Fryxell et P.A. Sims, with heavily silicified valve and thickened ridge between valve margin and vertical mantle; tilt $25^{\circ}$. Sample 130-806B-1H-2, 98-99 cm. 2. Internal view of Azpeitia neocrenulata (VanLandingham) G. Fryxell et T.P. Watkins. Sample 130-806B-1H-2, $88-89 \mathrm{~cm}$. 3. Thalassionema nitzschioides Grunow var. parva Heiden et Kolbe. One apex shown only; Sample 130-806B-1H-2, 88-89 cm. 4. Thalassiothrix sp., corroded, one apex only; Sample 130-806B-1H-4, 18-19 cm. 5. Azpeitia africana (Janish ex Schmidt) G. Fryxell et T.P. Watkins. External view. Note slits on mantle and central annulus; “ $0{ }^{\circ}$ point” at about 7 o' clock. Sample $130-806 \mathrm{~B}-1 \mathrm{H}-4,18-19 \mathrm{~cm}$. 6. Azpeitia sp. Internal view. Note central annulus, central labjate process, ring of marginal labiate processes, and one ring midway between margin and center of valve. Diameter $38 \mu \mathrm{m}$, nine areolae in $10 \mu \mathrm{m}$. Sample $130-806 \mathrm{~B}-1 \mathrm{H}-2,88-89 \mathrm{~cm}$. Scale bars: $1,2,5$, and $6=10 \mu \mathrm{m} ; 3$ and $4=5 \mu \mathrm{m}$. 